\section{Keputusan Penggunaan Layanan Gofood Selama Masa Pandemi Covid-19}

\author{
Muhammad Muiz Ikram \\ Program Studi Manajemen Pemasaran, Universitas Pembangunan Nasional Veteran Jakarta, \\ Indonesia \\ E-Mail: Muizsiregar1@gmail.com
}

\section{Lifestyle, \\ Service Quality, \\ Promotion,}

Purchasing Decision

\begin{abstract}
This research is a quantitative study of the most popular food delivery service in Indonesia, GoFood. The objective of this research is to prove whether the Purchasing Decision on GoFood services is influenced by the variables of Lifestyle, Service Quality, and Promotion. The population drawn from the research object was GoFood consumers who used services during the Covid-19 Pandemic. The number of samples in this study were 100 respondents. The author uses descriptive analysis and inferential analysis with the PLS analysis test tool. The output obtained in this study shows that the Lifestyle and Service Quality variables have a positive-significant influence on the Purchasing Decision variable. For the promotion variable, the purchasing decision is not influenced by the promotional variables in a positive-significant manner.
\end{abstract}

Keywords: Lifestyle; Quality of Service; Promotion; and Purchasing Decision

\begin{abstract}
ABSTRAK
Penelitian ini merupakan penelitian kuantitatif dari suatu layanan pesan antar makanan terpopuler di Indonesia yaitu GoFood. Objektif yang ingin dicapai pada penelitian ini adalah untuk membuktikan apakah Keputusan Pembelian pada layanan GoFood dipengaruhi dengan variabel Gaya Hidup, Kualitas Layanan, dan Promosi. Populasi yang diambil dari objek penelitian merupakan konsumen GoFood yang menggunakan layanan selama masa Pandemi Covid-19. Jumlah sampel pada penelitian ini adalah 100 responden. Penulis menggunakan analisis deskriptif dan analisis inferensial dengan alat uji analisis PLS. Keluaran yang didapatkan pada penelitian ini menunjukan variabel Gaya Hidup dan Kualitas Layanan memiliki pengaruh positif-signifikan terhadap variabel Keputusan Pembelian. Untuk variabel promosi, Keputusan Pembelian tidak dipengaruhi oleh varibel promosi secara positif-signifikan.
\end{abstract}

Kata kunci: Gaya Hidup; Kualitas Layanan; Promosi; dan Keputusan Pembelian.

\title{
PENDAHULUAN
}

Pada awal tahun 2020, Virus Covid-19 terkonfirmasi masuk ke Indonesia. Virus ini telah tersebar luas di hampir seluruh negara. Hal tersebut mengakibatkan perubahan status penyakit menjadi pademi. Akibat dari adanya situasi pandemi ini, banyak sekali aktivitas masyarakat yang terganggu akibat dari adanya kebijakan Pembatasan Sosial Berskala Besar (PSBB) dan Physical Distancing. Hal ini mengakibatkan aktivitas sosial masyarakat dan aktivitas ekonomi terganggu. Sehingga Indonesia terancam mengalami resesi (Kusuma, 2020). Salah satu pendapatan terbesar pemerintah bersumber dari Usaha Mikro Kecil dan Menengah (UMKM). UMKM merupakan salah satu tulang punggung negara. Banyak sekali sektor UMKM yang terancam gulung tikar akibat situasi pandemi. BPS melalui surveinya menyebutkan sektor yang paling terdampak sigifikan mengalami penurunan adalah sektor akomodasi dan makanan \& minuman. Penurunan pendapatan yang terjadi pada kedua sektor ini mencapai $92,47 \%$. Data ini diambil dari 34 ribu pelaku usaha UMKM di setiap sektor. (Yudha, 2020). Disisi lain, pada saat Indonesia mengalami resesi dan banyaknya UMKM yang gulung tikar, Gofood melalui aplikasi Gojek hadir untuk memberikan solusi baru bagi pengusaha UMKM sektor makanan dan minuman. Berdasarkan redaksi yang dilakukan oleh (Artanti, 2020), pada masa pandemi Covid-19, GoFood mengalami peningkatan jumlah transaksi sebanyak 20\% akibat adanya PSBB (Artanti, 2020). Pandemi Covid-19 berdampak pada berubahnya gaya

\section{JIMKES}

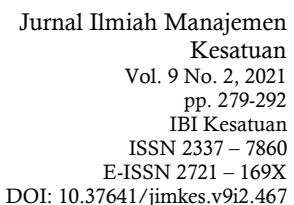

Submitted:
MARET 2021

Accepted: JUNI 2021 
Lifestyle,

Service Quality,

Promotion,

Purchasing Decision

\section{Hipotesis}

Model Penelitian Empirik

Model penelitian empirik menggambarkan suatu model yang menerangkan bagaimana hubungan antara variable independen dalam penelitian ini yaitu Gaya Hidup, Kualitas Layanan, dan Promosi tehadap variabel dependen yaitu Keputusan Pembelian. Berdasarkan uraian diatas, adapun model penelitian yang digunakan adalah sebagai berikut.

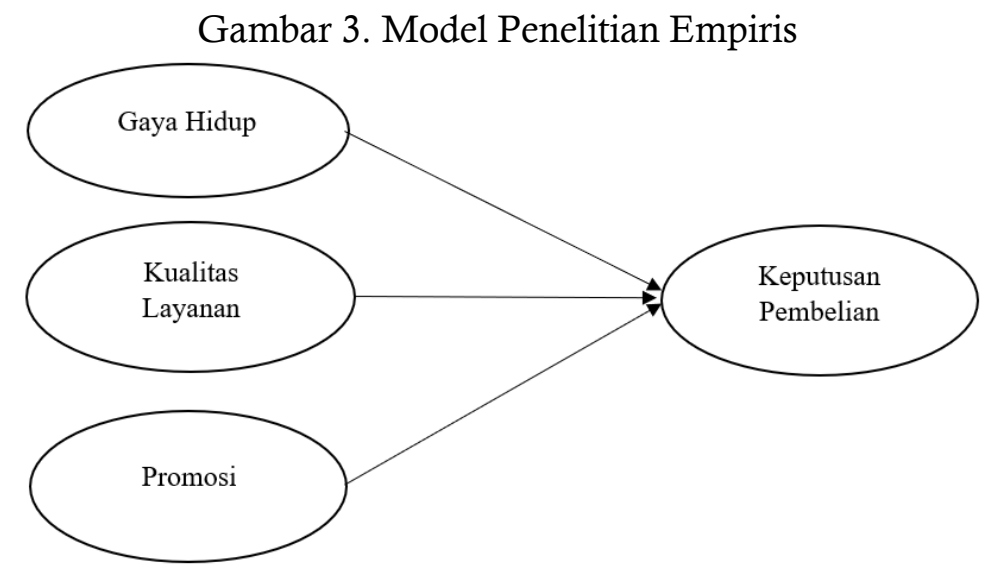

Sumber: Data diolah

Berdasarkan tujuan yang ingin dicapai pada penelitian ini, rumusan masalah, serta tinjauan pustaka yang telah diuraikan sebelumnya, Adapun hipotesis dalam penelitian ini adalah sebagai berikut:

H1: Diduga Gaya Hidup memiliki pengaruh positif terhadap Keputusan Pembelian.

H2: Diduga Kualitas Layanan memiliki pengaruh positif terhadap Keputusan Pembelian. H3: Diduga Promosi memiliki pengaruh positif terhadap Keputusan Pembelian.

\section{METODOLOGI PENELITIAN}

Penelitian ini terdiri dari variabel independent yaitu gaya hidup, kualitas layanan, dan promosi serta variabel dependen yaitu kualitas layanan. Populasi dalam penelitian ini yaitu konsumen yang berdomisili di Jakarta jakarta selatan, yang menggunakan layanan GoFood selama masa pandemi Covid-19. Teknik pengambilan sampel penelitian ini dilakukan menggunakan teknik non-probability sampling, yang mana tidak memberikan peluang yang sama untuk setiap unsur maupun populasi yang ditentukan untuk dipilih menjadi sampel (Sugiyono, 2019 hlm.131). Perhitungan sampel pada penelitian ini dilakukan dengan menggunakan lemeshow, maka diperoleh sampel sebannyak 96 orang responden dan dibulatkan menjadi 100 responden. Jenis data yang digunakan oleh peneliti adalah data kuantitatif. Data kuantitatif merupakan data yang angka yang diperoleh dan diolah ataupun dianalisis menggunakan perhitungan matematika (Radjab \& Jam'an, 2017 hlm. 111). Penelitian ini memiliki sumber data diperoleh melalui data primer. Data primer merupakan data yang didapatkan langsung 
dari lapangan (Sugiyono, 2019 hlm.9). Pengumpulan data dilakukan dengan teknik angket atau kuesioner, yang disebarkan melalui google form. Pengukuran dalam penelitian ini menggunakan skala likert. Teknik analisis data yang digunakan adalah analisis deksriptif dan inferensial menggunakan PLS. Analisis deskriptif pada penelitian ini dilakukan dengan mengintepretasikan jawaban responden melalui skala indeks, sedangkan analisis inferensial pada penelitian ini dilakukan melalui uji validitas, reliabilitas, koefisien determinasi, serta uji hipotesis yaitu uji-t yang diolah menggunakan software smart PLS 3.3.2.

\section{HASIL DAN PEMBAHASAN}

\section{Deskripsi Data Responden}

Dalam penelitian ini, populasi yang digunakan adalah pengguna layanan GoFood yang berdomisili atau sedang menetap di daerah Jakarta Selatan. Adapun responden terbagi menjadi beberapa karakteristik dari jenis kelamin, usia, pekerjaan, kecamatan, dan penghasilan selama sebulan dari responden. Pada penelitian ini, responden didominasi oleh pengguna layanan GoFood dengan jenis kelamin perempuan yaitu sebesar $65 \%$. Kelompok usia 20-30 tahun sebesar 86\%, Menurut pekerjaan didominasi oleh pelajar atau mahasiswa sebesar 91\%, menurut lokasi yaitu sebesar $35 \%$ yang berdomisili atau menetap di kelurahan Jagakarsa. Untuk pendapatan sebesar Rp.2-5 Juta yaitu sebesar 30\%.

Berdasarkan tabel diatas, hasil loading factor jawaban responden terhadap butir pernyataan terkait variabel-variabel penelitian yang diberikan dalam kuesioner penelitian dapat dilihat sebagai berikut:

\section{Persepsi responden tentang Keputusan Pembelian}

\begin{tabular}{ccccccc}
\hline $\begin{array}{c}\text { Keputusan } \\
\text { Pembelian }\end{array}$ & $\mathbf{1}$ & $\mathbf{2}$ & $\mathbf{3}$ & $\mathbf{4}$ & $\mathbf{5}$ & Indeks \\
\hline KP1 & 0 & 0 & 0 & 34 & 66 & 93,2 \\
\hline KP2 & 0 & 2 & 14 & 39 & 45 & 85,4 \\
\hline KP3 & 0 & 2 & 17 & 30 & 51 & 86 \\
\hline KP4 & 0 & 3 & 25 & 40 & 32 & 80,2 \\
\hline KP5 & 0 & 0 & 11 & 33 & 56 & 89 \\
\hline KP6 & 0 & 2 & 12 & 38 & 48 & 86,4 \\
\hline Rata - Rata Indeks & & & & & 86,7 \\
\hline
\end{tabular}

Hasil pengolahan data menunjukan KP 1 merupakan nilai tertinggi dengan nilai indeks 93,2. Adapun nilai indeks tersebut termasuk kategori tinggi berdasarkan metode tiga kotak. Dalam butir KP1 memuat pernyataan mengenai Merchant GoFood menawarkan paket menu makanan yang beragam. Artinya, responden memiliki persepsi bahwa Keputusan Pembelian dapat dipengaruhi dari beragamnya paket menu makanan yang ada pada layanan GoFood.

Hasil pengolahan data menunjukan KP4 merupakan nilai terrendah dengan nilai indeks sebesar 80,2. Adapun nilai indeks tersebut termasuk kategori tinggi berdasarkan metode tiga kotak. Dalam butir KP4 memuat pernyataan mengenai Estimasi pengiriman makanan pada layanan GoFood sesuai dengan keterangan pada aplikasi. Artinya, responden memiliki pandangan bahwa ketepatan pengiriman makanan masih sesuai dengan estimasi yang tertera pada aplikasi.

Secara keseluruhan skor yang diperoleh variabel Keputusan Pembelian memiliki hasil rata-rata 86,7. Adapun nilai indeks tersebut menurut three box method termasuk kedalam kategori tinggi. Hal tersebut mengindikasikan bahwa responden pengguna Layanan GoFood di Jakarta Selatan mengindikasikan bahwa indikator Keputusan Pembelian memiliki dampak yang tinggi terhadap variabel Keputusan Pembelian.

2. Persepsi responden terhadap Gaya Hidup

\begin{tabular}{ccccccc}
\hline \multirow{2}{*}{ Gaya Hidup } & $\mathbf{1}$ & $\mathbf{2}$ & $\mathbf{3}$ & $\mathbf{4}$ & $\mathbf{5}$ & Indeks \\
\hline $\mathrm{GH} 1$ & 0 & 1 & 4 & 36 & 59 & 90,6 \\
\hline $\mathrm{GH} 2$ & 0 & 0 & 5 & 22 & 73 & 93,6 \\
\hline $\mathrm{GH} 3$ & 4 & 13 & 52 & 19 & 12 & 64,4 \\
\hline
\end{tabular}

Service Quality,

Promotion,

Purchasing Decision 
Lifestyle,

Service Quality,

Promotion,

Purchasing Decision

282

\begin{tabular}{ccccccc} 
GH4 & 0 & 7 & 16 & 36 & 41 & 82,2 \\
\hline GH5 & 0 & 0 & 10 & 29 & 61 & 90,2 \\
\hline GH6 & 1 & 4 & 21 & 36 & 38 & 81,2 \\
\hline Rata - Rata Indeks & & & & & 83,7 \\
\hline
\end{tabular}

Hasil pengolahan data menunjukan GH2 dengan nilai 93,6 merupakan nilai tertinggi dengan nilai indeks. Adapun nilai indeks tersebut termasuk kategori tinggi berdasarkan metode tiga kotak. Dalam butir tersebut memuat pernyataan mengenai Layanan GoFood mempermudah konsumen memilih kuliner tanpa harus keluar rumah. Artinya responden memiliki persepsi yang sedemikian.

Selanjutnya, nilai indeks terendah pada variabel produk ini terdapat pada butir GH3 dengan nilai 64,4 . Adapun nilai indeks tersebut termasuk kategori sedang berdasarkan metode tiga kotak. Dalam butir tersebut memuat Layanan GoFood dapat memenuhi keinginan konsumen dalam menikmati kuliner. Pada butir GH3, responden memiliki persepsi bahwa Layanan GoFood cukup memenuhi keinginan konsumen dalam menikmati kuliner. Selanjutnya, rata-rata indeks skor jawaban pada variabel produk yakni 83,7. Adapun nilai indeks tersebut termasuk kategori tinggi berdasarkan metode tiga kotak. Yang artinya hal tersebut mengindikasikan bahwa responden merasakan bahwa indikator Gaya Hidup memiliki dampak yang tinggi terhadap variabel Gaya Hidup.

3. Persepsi responden terhadap Kualitas Layanan

\begin{tabular}{ccccccc}
\hline \multirow{2}{*}{ Kualitas Layanan } & \multicolumn{3}{c}{ Frekuensi } & \multicolumn{2}{c}{ Indeks } \\
& $\mathbf{1}$ & $\mathbf{2}$ & $\mathbf{3}$ & $\mathbf{4}$ & $\mathbf{5}$ & \\
\hline KL1 & 0 & 3 & 27 & 38 & 32 & 79,8 \\
\hline KL2 & 0 & 2 & 15 & 45 & 38 & 83,8 \\
\hline KL3 & 0 & 2 & 29 & 49 & 20 & 77,4 \\
\hline KL4 & 0 & 2 & 11 & 46 & 41 & 85,2 \\
\hline KL5 & 1 & 4 & 15 & 44 & 36 & 82 \\
\hline KL6 & 0 & 0 & 7 & 31 & 62 & 91 \\
\hline KL7 & 0 & 1 & 18 & 40 & 41 & 84,2 \\
\hline KL8 & 0 & 2 & 17 & 48 & 33 & 82,4 \\
\hline Rata - Rata Indeks & & & & & & 83,23 \\
\hline
\end{tabular}

Hasil pengolahan data menunjukan KL6, dengan hasil nilai indeks sebesar 91 merupakan nilai tertinggi. Adapun nilai indeks tersebut termasuk kategori tinggi berdasarkan metode tiga kotak. Adapun pernyataan pada KL6 yaitu mengenai Pesanan yang diantarkan sesuai dengan permintaan yang tertera di aplikasi. Dengan begitu artinya bahwa responden memiliki persepsi bahwa Pesanan yang diantarkan sesuai dengan permintaan yang tertera di aplikasi.

Selanjutnya Hasil pengolahan data menunjukan KL3, dengan nilai indeks sebesar 77,4 merupakan nilai terendah dengan nilai indeks. Adapun nilai indeks tersebut termasuk kategori tinggi berdasarkan metode tiga kotak. Adapun pernyataan pada butir KL3 yakni mengenai Waktu pengantaran makanan relatif cepat. Artinya bahwa responden memiliki persepsi setuju Waktu pengantaran makanan relatif cepat.

Secara keseluruhan rata-rata indeks pada variabel Kualitas Pelayanan memperoleh nilai 83,23. Yang mana nilai rata-rata indeks tersebut termasuk kedalam kategori tinggi. Artinya, hal tersebut mengindikasikan bahwa responden merasakan bahwa indikator Kualitas Layanan memiliki dampak yang tinggi terhadap variabel Kualitas Layanan.

4. Persepsi responden terhadap Promosi

\begin{tabular}{ccccccc}
\hline \multirow{2}{*}{ Promosi } & $\mathbf{1}$ & $\mathbf{2}$ & $\mathbf{3}$ & $\mathbf{4}$ & $\mathbf{5}$ & \multirow{2}{*}{ Indeks } \\
& 0 & 4 & 12 & 41 & 43 & 84,6 \\
\hline P1 & 0 & 6 & 9 & 45 & 40 & 83,8 \\
\hline P2 & 4 & 2 & 16 & 36 & 42 & 82 \\
\hline P3 & 3 & 1 & 18 & 28 & 50 & 84,2 \\
\hline P4 & 1 & 7 & 22 & 41 & 29 & 78 \\
\hline
\end{tabular}




\begin{tabular}{ccccccc} 
P6 & 1 & 5 & 31 & 37 & 26 & 76,4 \\
\hline Rata- Rata Indeks & & & & & 81,5 \\
\hline
\end{tabular}

Hasil pengolahan data menunjukan P1 dengan nilai 84,6 merupakan nilai tertinggi. Adapun nilai indeks tersebut termasuk kategori tinggi berdasarkan metode tiga kotak. Adapun pernyataan pada butir P1 yakni tampilan layanan GoFood unik dan kreatif di media sosial. Maka dapat diartikan bahwa responden memiliki persepsi bahwa tampilan layanan GoFood unik dan kreatif di media sosial.

Hasil pengolahan data menunjukan P6 dengan nilai indeks sebesar 76,4 merupakan nilai terendah. Nilai yang diperoleh butir P6 tersebut menurut three box method termasuk kedalam kategori tinggi. Adapun pernyataan yang terdapat dalam butir P6 yakni mengenai layanan keluhan pelanggan yang responsif. Maka dapat diartikan bahwa responden memiliki persepsi bahwa layanan keluhan pelanggan yang dimiliki GoFood responsif.

Secara keseluruhan rata-rata nilai indeks yang diperoleh sebesar 81,5 yang mana nilai indeks tersebut termasuk kedalam kategori tinggi. Maka hal tersebut mengindikasikan bahwa bahwa responden merasakan indikator Promosi memiliki dampak yang tinggi terhadap variabel Promosi.

Selanjutnya dilakukan uji validitas, uji reliabilitas, uji R-Square, uji Q-Square serta uji hipotesis dengan uji-t pada variabel gaya hidup, promosi penjualan dan motivasi belanja hedonis terhadap impulse buying. Uji validitas dan reliabilitas pada penelitian ini dapat dilihat pada tabel berikut:

\section{a. Uji Validitas (Convergent Validity)}

\section{1) Uji validitas model indikator atau dimensi reflektif}

Berdasarkan uji convergent validity, loading factor serta AVE senilai 0,50 hingga 0,60 telah dinyatakan cukup (Hidayat, 2018, Hlm.153). Sedangkan berdasarkan uji discriminant validity, AVE >0,50 (I Ghozali, 2014, hlm.39).

Tabel 18. Average Variance Extracted (AVE)

\begin{tabular}{cc}
\hline Variabel & Average Variance Extracted (AVE) \\
\hline Gaya Hidup (X1) & 0.435 \\
\hline $\begin{array}{c}\text { Kualitas Layanan } \\
\text { (X2) }\end{array}$ & 0.507 \\
\hline Promosi (X3) & 0.534 \\
\hline
\end{tabular}

\section{Sumber: Data diolah}

Pada tabel di atas, menunjukkan nilai AVE $>0.50$ untuk variabel dengan indikator reflektif yang diteliti yaitu Kualitas Layanan dan Promosi. Berdasarkan data di atas, nilai terendah sebesar 0.435 pada variabel Gaya Hidup dan nilai tertinggi 0.534 pada variabel Promosi. Dapat disimpulkan variabel Kualitas Layanan dan Promosi valid karena nilainya menunjukan $>0.50$ sesuai syarat yang dijelaskan oleh (I Ghozali 2014, hlm.39). Tetapi masih ada 1 variabel yang memiliki output <0,5 yaitu variabel Gaya Hidup. Dimana hasil tersebut tidak valid, dimana indikator variabel Gaya Hidup tidak dapat dimengerti oleh responden yang merupakan konsumen GoFood dan dianggap tidak relevan. Sehingga perlu dilakukan re-estimasi sebagai berikut:

\begin{tabular}{cc} 
Tabel 19. Average Variance Extracted (AVE) setelah Re-Estimasi \\
\hline Variabel & Average Variance Extracted (AVE) \\
\hline Gaya Hidup (X1) & 0.474 \\
\hline Kualitas Layanan (X2) & 0.507 \\
\hline Promosi (X3) & 0.534 \\
\hline
\end{tabular}

Sumber: Data diolah

Dari hasi penghitungan ulang, masih terlihat variabel Gaya Hidup masih memiliki output $<0,5$. Sehingga langkah selanjutnya adalah dengan menghapus kembali salah satu indikator pada variabel Gaya Hidup, yaitu GH12. Dimana diperoleh sebagai berikut:

\section{Lifestyle, \\ Service Quality, \\ Promotion,}

Purchasing Decision

283 
Lifestyle,

Service Quality,

Promotion,

Purchasing Decision

284
Tabel 20. Average Variance Extracted (AVE) setelah Re-Estimasi kedua

\begin{tabular}{cc}
\hline Variabel & $\begin{array}{c}\text { Average Variance Extracted } \\
\text { (AVE) }\end{array}$ \\
\hline Gaya Hidup (X1) & 0.539 \\
\hline Kualitas Layanan (X2) & 0.507 \\
\hline Promosi (X3) & 0.534
\end{tabular}

Sumber: Data diolah

Dari hasil re-estimasi kedua, nilai AVE $>0.50$ pada variabel dengan indikator reflektif yang diteliti yaitu Gaya Hidup, Kualitas Layanan, dan Promosi. Nilai terendah sebesar 0.507 pada variabel Kualitas Layanan dan nilai tertinggi adalah sebesar 0.539 pada Gaya Hidup. Maka dapat disimpulkan bahwa variabel Gaya Hidup, Kualitas Layanan, dan Promosi adalah valid karena telah memenuhi syarat di atas 0.50 sesuai syarat yang dijelaskan oleh (Ghozali $2014 \mathrm{hlm} .39$ ). Hasil AVE di atas telah menyatakan bahwa variabel yang memiliki indikator reflektif telah valid.

Convergent Validity melalui Output Loading Factor

\begin{tabular}{lccc}
\hline & Gaya Hidup & Kualitas Layanan & Promosi \\
\hline GH1 & $\mathbf{0 . 7 2 4}$ & & \\
\hline GH2 & $\mathbf{0 . 8 1 6}$ & & \\
\hline GH3 & $\mathbf{0 . 6 2 4}$ & & \\
\hline GH4 & $\mathbf{0 . 7 5 9}$ & 0.734 & \\
\hline KL1 & 0.768 & \\
\hline KL2 & $\mathbf{0 . 6 0 2}$ & \\
\hline KL3 & $\mathbf{0 . 6 9 0}$ & \\
\hline KL4 & $\mathbf{0 . 7 9 8}$ & $\mathbf{0 . 7 3 6}$ \\
\hline KL5 & $\mathbf{0 . 6 9 1}$ & $\mathbf{0 . 7 8 3}$ \\
\hline KL6 & $\mathbf{0 . 7 0 1}$ & $\mathbf{0 . 7 5 3}$ \\
\hline KL7 & $\mathbf{0 . 6 9 4}$ & $\mathbf{0 . 6 8 6}$ \\
\hline KL8 & & $\mathbf{0 . 7 8 3}$ \\
\hline P1 & & $\mathbf{0 . 6 3 5}$ \\
\hline P2 & & \\
\hline P4 & & \\
\hline P5 & & \\
\hline P6 & & \\
\hline
\end{tabular}

Sumber: Data diolah

Dari hasil olah data di atas, menunjukan bahwa nilai loading factor $>0.50$. Nilai tertinggi adalah sebesar 0.816 untuk indikator $\mathrm{GH} 2$ dan nilai terendah adalah 0.602 untuk indikator KL3. Dapat disimpulkan bahwa indikator reflektifpada penelitian ini dinyatakan valid.

2) Uji validitas model indikator atau dimensi formatif

Dapat dilakukan dengan cara menganalisis nilai cross loading dengan ketentuan nilai konstruk $>0.50$ valid. Selain itu dapat pula dianalisis menggunakan nilai VIF. Nilai VIF outer model dengan skor $<5$, dapat dinyatakan konstruk telah valid atau layak dipertimbangkan ke analisis berikutnya.

Tabel 22. Cross Loading Output PLS

\begin{tabular}{lc}
\hline & Keputusan Pembelian \\
\hline KP1 & 0.545 \\
\hline KP2 & 0.626 \\
\hline KP3 & 0.593 \\
\hline KP4 & 0.590 \\
\hline KP5 & 0.772 \\
\hline
\end{tabular}

Sumber: Data diolah 
Dalam mengukur cross loading indikator yang dianggap valid jika nilai konstruk $>0.50$. Dari data di atas, tertera bahwa seluruh indikator dari variabel Keputusan Pembelian memiliki output $>0.50$. Hal ini menandakan variabel Keputusan Pembelian dinyatakan valid. Selain itu dapat pula dianalisis menggunakan nilai VIF yaitu sebagai berikut:

Tabel 23. Nilai VIF Variabel Keputusan Pembelian

\begin{tabular}{lc}
\hline & Nilai VIF Keputusan Pembelian \\
\hline KP1 & 1.173 \\
\hline KP2 & 1.532 \\
\hline KP3 & 1.249 \\
\hline KP4 & 1.439 \\
\hline KP5 & 1.333 \\
\hline
\end{tabular}

Sumber: Data diolah

Dari hasil pengolahan data di atas, nilai VIF dari variabel kualitas layanan pada masing-masing indikator memiliki nilai $<5$, sehingga dapat disimpulkan variabel kualitas layanan dapat dinyatakan valid atau layak dipertimbangkan ke analisis berikutnya. Nilai VIF tersebut memperkuat nilai cross loading pada indikator formatif pada penelitian ini, sehingga dapat dilakukan pengujian data selanjutnya.

\section{b. Uji Reliabilitas}

Uji Reliabilitas merupakan uji yang dapat dijadikan sebagai alat ukur dengan menghitung dan menganalisis data composite reability dan alpha cronbach pada sebuah indikator di dalam suatu variabel dan dikatakan reliabel jika jawaban responden konsisten dan stabil (I Ghozali, 2014, hlm.174).

1) Uji reliabilitas pada model indikator atau dimensi reflektif

Untuk uji reliabilitas pada indikator reflektif meliputi Gaya Hidup, Kualitas Layanan, dan Promosi dapat diukur menggunakan composite reliability dan cronbach alpha (I Ghozali, 2014 hlm.65). Uji dapat dinyatakan reliabel jika nilai tersebut $>0,70$.

Tabel 24. Uji Reliabilitas

\begin{tabular}{ccc}
\hline Variabel & Composite Reliability & Cronbach's Alpha \\
\hline Gaya Hidup & 0.822 & 0.716 \\
\hline Kualitas Layanan & 0.891 & 0.860 \\
\hline Promosi & 0.873 & 0.826 \\
\hline
\end{tabular}

Sumber: Data diolah

Dari hasil olah data di atas, nilai pada semua konstruk $>0.7$ yang artinya semua variabel dinyatakan reliabel. Nilai terendah Composite Reliability adalah 0.822 pada konstruk Gaya Hidup, dan nilai tertinggi yaitu sebesar 0.891 pada konstruk Kualitas Layanan. Dari hasil output SmartPLS membuktikan bahwa setiap butir pernyataan pada variabel Gaya Hidup, Kualitas Layanan, dan Promosi adalah reliabel. Sehingga dapat diartikan bahwa kuesioner bersifat relevan.

Dapat dilihat dari data yang telah diolah, hasil Cronbach's Alpha dari variabel Gaya Hidup menunjukkan nilai 0.716 yang menunjukkan bahwa tingkat reliabilitas yang sangat baik. Pada variabel Kualitas Layanan memiliki nilai yaitu 0.860 yang menunjukkan tingkat reliabilitas yang sangat baik. Serta pada variabel Promosi memiliki nilai yaitu 0.826 . Hal tersebut dapat disimpulkan bahwa variabel dengan indikator reflektif pada penelitian ini yaitu Gaya Hidup, Kualitas Layanan, dan Promosi adalah sangat reliabel terhadap masing-masing konstruknya karena menurut (Ghozali, 2014 hlm.52) nilai $>0.8-1.00$ artinya adalah sangat reliabel.

\section{2) Uji reliabilitas untuk model indikator atau dimensi formatif}

Dapat dilakukan melalui nilai rata-rata outer weight. Jika nilai rata-rata outer weight $>0,70$, maka dapat dinyatakan indikator atau dimensi tersebut memiliki reliabitas yang baik.
Service Quality,

Promotion,

Purchasing Decision 
Lifestyle,

Service Quality,

Promotion,

Purchasing Decision

\begin{tabular}{cc}
\multicolumn{2}{c}{ Tabel 25. Outer Weight } \\
\hline \multicolumn{2}{c}{ Keputusan Pembelian } \\
\hline KP1 & 0.288 \\
\hline KP2 & 0.194 \\
\hline KP3 & 0.217 \\
\hline KP4 & 0.216 \\
\hline KP5 & 0.427 \\
\hline KP6 & 0.297
\end{tabular}

Sumber: Data diolah

Rumus menghitung rata-rata outer weight adalah sebagai berikut:

$=(1-($ matrix 1$))+(1-($ matrix 2$))+\ldots(1-($ matrix X) $) /$ jumlah variabel

$=(1-0.288)+(1-0.194)+(1-0.217)+(1-0.216)+(1-0.427)+(1-0.297)$

$=4,421 / 7$

$=0.737$

Dari hasil perhitungan di atas, mendapatkan hasil rata-rata outer weight sebesar 0.737 yang artinya bahwa rata-rata outer weight $>0.70$. Maka dapat disimpulkan bahwa indikator atau dimensi formatif pada penelitian ini yaitu Keputusan Pembelian memiliki reliabilitas yang baik (Abdillah \& Hartono, 2015).

IV.4.2 Model Struktural (Inner Model)

Berikut ini adalah hasil inner model dengan melihat $\mathrm{R}$ square dan nilai hasil ujit t pada alat uji analisis PLS:

Gambar 9. Model Struktural

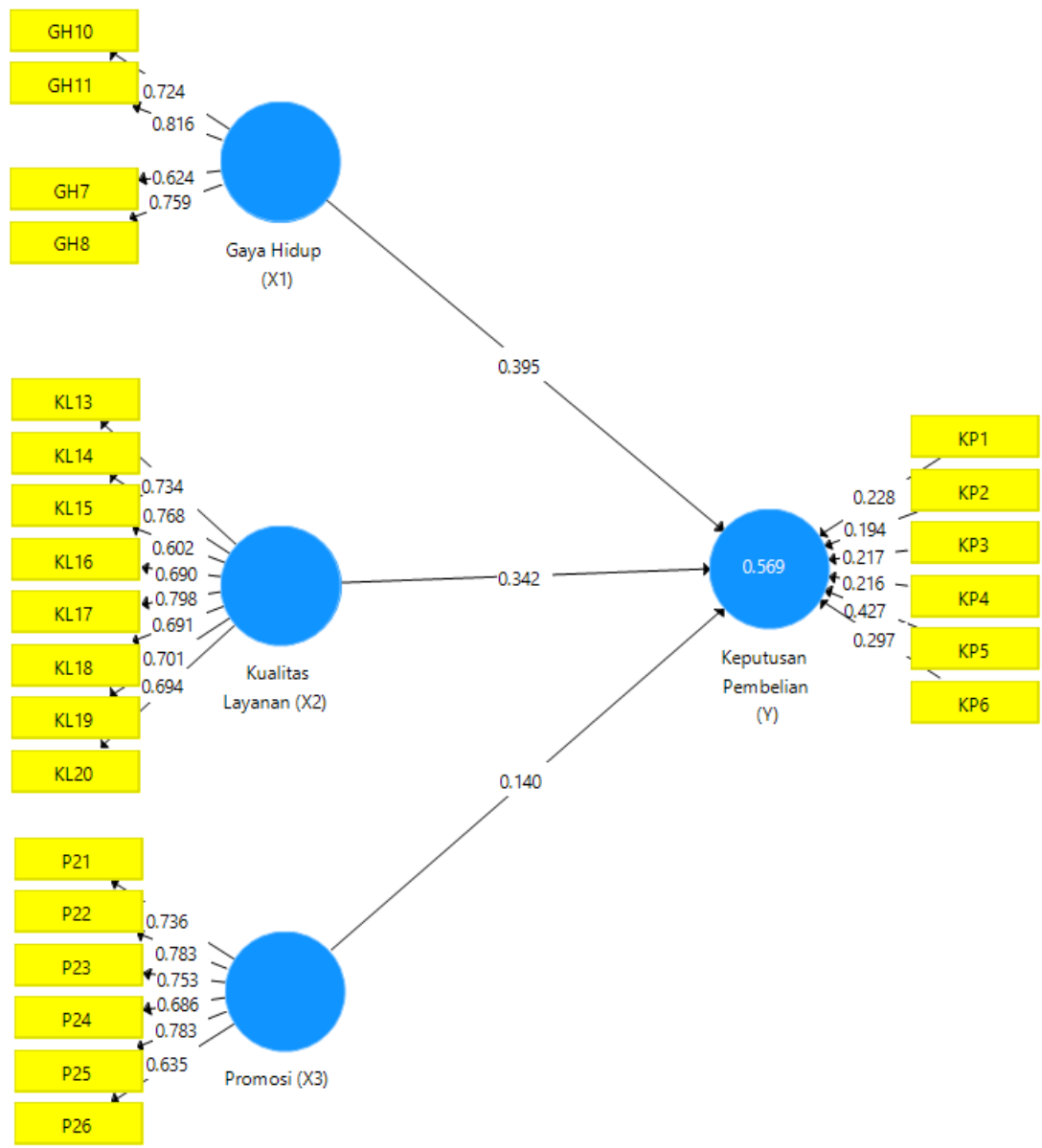

Sumber: Data diolah 
Uji hipotesis pada penelitian ini meliputi Uji Koefisien Determinasi $\left(\mathrm{R}^{2}\right)$ dan statistik uji t. Uji t ini digunakan untuk menganalisis apakah ada pengaruh antara Gaya Hidup (X1), Kualitas Layanan (X2), dan Promosi (X3) terhadap Keputusan Pembelian (Y).

\section{IV.5.1 Uji Koefisien Determinasi $\left(\mathbf{R}^{2}\right)$}

Adapun hasil pengolahan data $P L S$ mengenai R square adalah sebagai berikut:

Tabel 26. Nilai R-square

\begin{tabular}{cc}
\hline Variabel & R square \\
\hline $\begin{array}{c}\text { Keputusan } \\
\text { Pembelian (Y) }\end{array}$ & 0.569 \\
\hline
\end{tabular}

Sumber: Data diolah

Dari data yang telah diolah di atas, menujukkan besarnya $\mathrm{R}$ square Kualitas Layanan sebesar 0.569, maka dengan begitu menunjukkan konstribusi antara Gaya Hidup, Kualitas Layanan, dan Promosi sebesar 56.9\%, sehingga sebesar 43.1\% untuk sisanya dari $\mathrm{R}$ square dipengaruhi oleh variabel lain.

\section{IV.5.2 Uji t}

Diketahui $t_{\text {tabel }}$ yang digunakan pada penelitian ini yaitu 1.660 yang diperoleh dari rumus $\mathrm{df}=\mathrm{N}-\mathrm{k}$ atau $\mathrm{df}=100-4=96$, dengan tingkat signifikansi $10 \%$ atau 0.1 . Berdasarkan hasil pengolahan data untuk uji statistik $\mathrm{t}$ (uji t), maka diperoleh hasil sebagai berikut:

Tabel 27. Hasil Uji Statistik t

\begin{tabular}{lcccc}
\hline & $\begin{array}{c}\text { Original } \\
\text { Sample }(\mathrm{O})\end{array}$ & $\begin{array}{c}\text { T Statistik } \\
(|\mathrm{O} / \mathrm{STDEV}|)\end{array}$ & P Values \\
\hline $\begin{array}{l}\text { Gaya Hidup } \\
\text { Pembelian }\end{array}$ & Keputusan & 0.395 & 3.503 & 0.001 \\
\hline $\begin{array}{l}\text { Kualitas Layanan } \\
\text { Pembelian }\end{array}$ & Keputusan & 0.342 & 2.334 & 0.020 \\
\hline Promosi $\rightarrow$ Keputusan Pembelian & 0.140 & 1.291 & 0.197 \\
\hline
\end{tabular}

\section{Sumber: Data diolah}

Berdasarkan tabel di atas, dapat dilihat bahwa hasil pengujian pada variabel Gaya Hidup terhadap Keputusan Pembelian memiliki hubungan yang positif, hal ini ditunjukkan dengan nilai original sample atau nilai korelasi sebesar 0.395. Dari hasil pengolahan data uji statistik $\mathrm{t}$ menunjukkan bahwa nilai $\mathrm{t}_{\text {hitung }} 3.503>\mathrm{t}_{\text {tabel }} 1.660$, yang dapat disimpulkan bahwa Gaya Hidup berpengaruh terhadap Keputusan Pembelian. Hal ini sejalan dengan nilai signifikan $(\mathrm{P}$ Value) sebesar $0.001<0.1$ yang artinya bahwa variabel Gaya Hidup berpengaruh positif dan signifikan terhadap Keputusan Pembelian, atau dengan kata lain $\mathrm{H} 1$ diterima.

Berdasarkan tabel di atas, dapat dilihat pula hasil pengujian variabel Kualitas Layanan terhadap Keputusan Pembelian memiliki hubungan yang positif. Hal ini ditunjukkan dengan nilai original sample atau nilai korelasi sebesar 0.342 . Dari hasil pengolahan data uji statistik $\mathrm{t}$ menunjukkan bahwa nilai $\mathrm{t}_{\text {hitung }} 2.334>\mathrm{t}_{\text {tabel }} 1.660$, maka dapat disimpulkan bahwa Kualitas Layanan memiliki pengaruh terhadap Keputusan Pembelian. Hal ini sejalan dengan nilai signifikan (P Value) sebesar $0.020<0.1$, yang artinya bahwa variabel Kualitas Layanan berpengaruh positif dan signifikan terhadap variabel Keputusan Pembelian, atau dengan kata lain $\mathrm{H} 2$ diterima.

Berdasarkan tabel di atas, dapat dilihat pula hasil pengujian variabel Promosi terhadap Keputusan Pembelian memiliki hubungan yang positif. Hal ini ditunjukkan dengan nilai original sample atau nilai korelasi sebesar 0.140 . Dari hasil pengolahan data uji statistik $t$ menunjukkan bahwa nilai nilai $t_{\text {hitung }} 1.291<\mathrm{t}_{\text {tabel }} 1.660$, maka dapat disimpulkan bahwa Promosi tidak memiliki pengaruh terhadap Keputusan Pembelian. Hal ini sejalan dengan nilai signifikan (P Value) sebesar $0.197>0.1$, yang artinya bahwa variabel Promosi tidak berpengaruh positif dan tidak signifikan terhadap variabel Keputusan Pembelian, atau dengan kata lain $\mathrm{H} 3$ ditolak.

\section{Pembahasan}

Service Quality,

Promotion,

Purchasing Decision 
Lifestyle,

Service Quality,

Promotion,

Purchasing Decision

288

Berdasarkan hasil penelitian yang telah dilakukan mengenai analisis Gaya Hidup, Kualitas Layanan, dan Promosi terhadap Keputusan Pembelian pada layanan GoFood dengan menggunakan metode Partial Least Square (PLS) dan software SmartPLS 3.0 maka diperoleh hasil sebagai berikut:

\section{Pengaruh Gaya Hidup terhadap Keputusan Pembelian}

Berdasarkan hasil pengujian hipotesis pada penelitian ini menunjukkan variabel Gaya Hidup terhadap Keputusan Pembelian memiliki hubungan yang positif Sehingga dapat diartikan bahwa variabel Gaya Hidup mampu mengukur Keputusan Pembelian layanan GoFood selama masa pandemi Covid-19.

Artinya dalam hal ini indikator-indikator yang digunakan pada variabel Gaya Hidup yaitu aktifitas, minat, dan opini dianggap telah memberikan kontribusi yang besar terhadap perannya untuk mempengaruhi Keputusan Pembelian. Berdasarkan redaksi yang dilakukan oleh (Dianawanti, 2020), pandemi Covid-19 berdampak pada berubahnya gaya hidup masyarakat Indonesia. Kebijakan Physical Distancing dan PSBB membuat masyarakat mengandalkan teknologi digital, dengan menjalani kehidupan sosial yang sangat terbatas.

Hasil penelitian ini sejalan dengan beberapa penelitian sebelumnya yang dilakukan oleh (Sukmawati \& Ekasasi, 2020), (Nguyen et al., 2020), (Amaliah et al., 2020), (Wibowo \& Riyadi, 2017), (Minarti \& Nainggolan, 2020), dan (Rahmah et al., 2018) yang menyatakan bahwa Gaya Hidup memiliki pengaruh terhadap variabel dependen yaitu Keputusan Pembelian. Pada penelitian tersebut dijelaskan bagaimana Gaya Hidup memiliki pengaruh yang kuat terhadap keputusan Pembelian.

\section{Pengaruh Kualitas Layanan terhadap Keputusan Pembelian}

Berdasarkan hasil pengujian hipotesis pada penelitian ini menunjukkan variabel Kualitas Layanan terhadap Keputusan Pembelian memiliki hubungan yang positif Sehingga dapat diartikan bahwa variabel Kualitas Layanan GoFood mampu mempengaruhi Keputusan Pembelian pengguna layanan GoFood selama masa pandemi Covid-19.

Hal tersebut menunjukkan bahwa pengaruh Kualitas Layanan terhadap Keputusan Pembelian signifikan dan searah, artinya kenaikan Kualitas pelayanan akan membuat pelanggan GoFood semakin sering melakukan pembelian. Pernyataan ini sesuai dengan penelitian yang dilakukan oleh (Widayat \& Artika, 2019). Konsumen yang merasa puas terhadap layanan yang diberikan oleh Layanan GoFood akan berpengaruh pada suatu keputusan pembelian. Selain itu hal ini dipengaruhi juga oleh salah satu indikator Kualitas Layanan yang dimiliki oleh layanan GoFood yaitu responsif yang membuat layanan GoFood menjadi layanan pesan antar makanan terbaik di dunia diluar China (Agustin, 2018).

Hasil penelitian ini sejalan dengan beberapa penelitian sebelumnya yang dilakukan oleh (Juhaeri, 2018), (Iqbal \& Kadir, 2019), (Pahlevi, 2019), (Minarti \& Nainggolan, 2020), dan(Ngaliman et al., 2020) yang menyatakan bahwa Kualitas Layanan memiliki pengaruh terhadap variabel dependen Keputusan Pembelian. Pada penelitian tersebut dijelaskan bagaimana upaya agar dapat memunculkan dan meningkatkan Kualitas Layanan yang diterapkan sehingga memunculkan transaksi pembelian.

\section{Pengaruh Promosi terhadap Keputusan Pembelian}

Berdasarkan hasil pengolahan data uji t, variabel promosi tidak berpengaruh terhadap Keputusan Pembelian. Dengan demikian hal tersebut dapat diartikan bahwa Promosi tidak berpengaruh dan tidak signifikan terhadap Keputusan Pembelian.

Artinya dalam variabel Promosi yang menggunakan indikator periklanan, promosi penjualan, dan hubungan masyarakat dianggap tidak berkontribusi dalam mempengaruhi variabel Keputusan Pembelian. Hal ini dapat terjadi karena pemesanan makanan berbasis aplikasi bukan lagi menjadi suatu kebutuhan sekunder, tetapi sudah menjadi kebutuhan primer. Sehingga masyarakat tidak terlalu bergantung lagi dengan ada atau tidaknya promosi yang dimiliki oleh layanan GoFood. Hal ini sejalan dengan riset yang dilakukan oleh LD FEB UI yaitu Sebanyak 65\% responden lebih sering menggunakan layanan GoFood dibandingkan sebelum pandemi (Primaldhi, 2020). 
Hasil pengolahan data yang telah dilakukan berbanding terbalik dengan penelitian yang dilakukan oleh (Farahnur \& Ariani, 2020), (Rahmah et al., 2018), (Kevin et al., 2019), dan (Iqbal \& Kadir, 2019) menyatakan bahwa Promosi berpengaruh signifikan terhadap Keputusan Pembelian. hal tersebut disebabkan karena adanya perubahan keadaan di saat Pandemi ini, kebanyakan orang melakukan transkasi pada layanan GoFood tidak didorong dengan adanya promo tetapi sudah menjadi kebutuhan dasar dan menjadi kebiasaan untuk menggunakan layanan GoFood.

\section{Simpulan}

Dari hasil pengujian yang telah dilakukan menggunakan analisis Partial Least Square (PLS) mengenai Keputusan Penggunaan Layanan GoFood Selama Masa Pandemi Covid-19, dapat disimpulkan sebagai berikut:

a. Penelitian menghasilkan kesimpulan bahwa variabel Gaya Hidup berpengaruh-positif dan signifikan terhadap Keputusan Pembelian. Artinya Gaya Hidup pengguna Layanan GoFood yang tinggal di daerah Jakarta Selatan dapat mempengaruhi Keputusan Pembelian.

b. Selanjutnya penelitian menghasilkan bahwa variabel Kualitas Layanan berpengaruhpositif dan signifikan terhadap Keputusan Pembelian. Artinya Kualitas Layanan GoFood memberikan pengaruh terhadap Keputusan Pembelian pengguna layanan GoFood.

c. Terakhir penemuan dari penelitian ini menyatakan variabel Promosi tidak berpengaruh positif-terhadap Keputusan Pembelian secara signifikan. Hasil ini tidak menunjukan kesesuaian dengan hipotesis yang telah diduga sebelumnya oleh penulis dimana terdapat pengaruh antara variabel promosi dengan Keputusan Pembelian.

\section{DAFTAR PUSTAKA}

[1] Abdillah, W., \& Hartono, J. (2015). Partial Least Square (PLS) - alternatif structural equation modeling (SEM) dalam penelitian bisnis. CV Andi Offset.

[2] Agustin, D. (2018). Nadiem Makarim Bagi Cerita Soal Awal Mula Gofood. Republika. $\quad$ https://republika.co.id/berita/gayahidup/kuliner/18/01/12/p2fro6328-nadiem-makarim-bagi-cerita-soal-awal-mulagofood

[3] Amaliah, R. R., Jusni, \& Munir, A. R. (2020). The influence of lifestyle, motivation, perception and attitude toward the purchase decision of eco friendly environment straw (case study on the management students of hasanuddin university). Hasanuddin Journal of Applied Business and Entrepreneurship, 3(2), 93-104. https://doi.org/10.26487/hjabe.v3i2.326

[4] Artanti, A. ayu. (2020). Transaksi GoFood Naik 20\% saat Pandemi. Medcom.Id. https://www.medcom.id/ekonomi/bisnis/eN406jwN-transaksi-gofood-naik-20saat-pandemi

[5] Dianawanti, V. (2020). Riset Tunjukkan Gaya Hidup Orang Indonesia Berubah karena Virus Corona Covid-19. Liputan6.Com. https://www.liputan6.com/bola/read/4225707/riset-tunjukkan-gaya-hiduporang-indonesia-berubah-karena-virus-corona-covid-19

[6] Farahnur, V. P., \& Ariani, M. N. (2020). Analysis of Marketing Mix on Purchase Decision of The Body Shop in Pejaten Village Mall Outlet. Internattional Humanities and Applied Sciences Journal (IHASJ), 3(1).

[7] Ghozali, I. (2014). Sctructural Equation Modeling, Metode Alternatif dengan Partial Least Square (PLS) (4th ed.). Universitas Diponogoro.

[8] Hastuti, R. K. (2019). GoFood kuasai 75\% Pangsa Pasar Indonesia. CNBC Indonesia. $\quad$ https://www.cnbcindonesia.com/tech/20190923131149-37101425/gofood-kuasai-75-pangsa-pasar-indonesia

[9] Hidayat, A. (2018). PLS SEM: Pengukuran Kecocokan Model (Inner dan Outer).

[10] Iqbal, M., \& Kadir, A. (2019). Analisis Pengaruh Kualitas Pelayanan dan Promosi Terhadap Keputusan Pembelian Pada Merchant GoFood Festival Duta Mall
Lifestyle,
Service Quality,

Promotion,

Purchasing Decision

289 
Lifestyle,

Service Quality,

Promotion,

Purchasing Decision

290

Banjarmasin. Jurnal Ilmiah Ekonomi Bisnis, 5(2), 227-237. https://doi.org/https://doi.org/10.35972/jieb.v6i2.350

[11] Jayani, D. H. (2019). Pemesanan Makanan secara Online Makin Digemari. Databoks. https://databoks.katadata.co.id/datapublish/2019/09/26/pemesananmakanan-secara-online-makin-digemari

[12] Juhaeri. (2018). The Influence of Brand Image, Service Quality, Price Perception and Trust on the Purchase Decision of Welding Workshop Welding Www.Kanopirumah.Com. Pinisi Discretion Review, 2(1), 17-24. https://doi.org/10.26858/pdr.v2i1.13219

[13] Kevin, C., Handoyo, S., Hondo, K. P., \& Fitriano, A. (2019). Pengaruh Kualitas Produk Dan Promosi Terhadap Keputusan Pembelian Rem Cakram Dan Rem Tromol Motor Honda Matic Pada Pt. Mega Anugerah Mandiri Medan. Wahana Inovasi : Jurnal Penelitian Dan Pengabdian Masyarakat UISU, 8(1), 44-53.

[14] Kotler, \& Keller. (2016). Marketing Management (14th ed.). BPFE.

[15] Kotler, P., \& Amstrong, G. (2012). Manajemen Pemasaran (Prinsip-prinsip manajemen pemasaran) (1st ed.). Erlangga.

[16] Kusuma, H. (2020). Ekonomi RI Babak Belur Dihantam Corona. DetikFinance. https://finance.detik.com/berita-ekonomi-bisnis/d-5193430/ekonomi-ri-babakbelur-dihantam-corona

[17] Minarti, M. S., \& Nainggolan, N. P. (2020). Pengaruh Gaya Hidup, Promosi, dan Kualitas Pelayanan terhadap keputusan Pembelian pada Toko Online Shopee. Jurnal Ilmiah Kohesi, 4(3), 210-217. https://kohesi.sciencemakarioz.org/index.php/JIK/article/view/171

[18] Ngaliman, Titik, D., \& Raymond. (2020). Pengaruh Kualitas Layanan, Harga, dan Promosi Terhadap Keputusan Pembelian Jasa Grab di Batam. Program Studi Manajemen, Fakultas Ekonomi Universitas Batam. https://www.academia.edu/40475924/Jurnal_Skripsi_Pengaruh_Kualitas_Laya nan_Harga_dan_Promosi_Terhadap_Keputusan_Pembelian_Jasa_GRAB_di_Bat am

[19] Nguyen, N.-L., Tran, T.-T., \& Vo, M.-P. (2020). The Effect of Lifestyle, Brand Image and Personalities on Smartphone Purchase Decision of Consumers in Hochiminh City. International Journal of Innovative Science and Research Technology, 5(3). https://ijisrt.com/assets/upload/files/IJISRT20MAR122.pdf

[20] Pahlevi, M. R. (2019). Pengaruh Kualitas Layanan, Harga, dan Promosi terhadap Keputusan Menginap di Hotel Aston Jember. Universitas Jember.

[21] Primaldhi, A. (2020). Riset LD: Perilaku Baru Konsumen Indonesia dalam Bertransaksi Digital di Masa Pandemi COVID-19. Lembaga Demografi Fakultas Ekonomi Dan Bisnis Universitas Indonesia. https://ldfebui.org/riset-ld-perilaku-baru-konsumenindonesia-dalam-bertransaksi-digital-di-masa-pandemi-covid-19/

[22] Radjab, E., \& Jam'an, A. (2017). Metodologi Penelitian Bisnis. Lembaga Perpustakaan dan Penerbitan Universitas Muhammadiyah Makasar.

[23] Rahmah, K., Sumarwan, U., \& Najib, M. (2018). The effect of brand equity, marketing mix, and lifestyle toward purchase decision at coffee shop in bogor. Journal of Consumer Sciences, 3(2), 01-15. https://media.neliti.com/media/publications/279438-the-effect-of-brand-equitymarketing-mix-cf8bb694.pdf

[24] Sugiyono. (2019). Metode Penelitian Kuantitatif, Kualitatif dan R\&D. Alfabeta CV.

[25] Sukmawati, N., \& Ekasasi, S. R. (2020). Pengaruh Gaya Hidup, Kualitas Produk, dan Promosi terhadap Keputusan Pembelian Produk Makanan Sehat Soyjoy. Cakrawangsa Bisnis, $1(1)$. http://journal.stimykpn.ac.id/index.php/cb/article/view/125/61

[26] Supriyatna, I. (2020). Promo GoFood, Ada Diskon hingga Rp 100.000. Kompas.Com. https://money.kompas.com/read/2020/10/07/163900426/promogofood-ada-diskon-hingga-rp-100.000 
[27] Wibowo, \& Riyadi. (2017). Pengaruh Gaya Hidup, Prestise Dan Kelompok Referensi Terhadap Keputusan Pembelian. Prosiding Seminar Nasional Riset Manajemen $\&$

Bisnis. https://publikasiilmiah.ums.ac.id/bitstream/handle/11617/8981/sansetmab201 7_2.pdf?sequence $=1 \&$ isAllowed $=\mathrm{y}$

[28] Widayat, \& Artika, S. Y. (2019). Kualitas Situs Web, Kepercayaan, Kepuasan dan Loyalitas Pembelanja Muda di Toko Online. 17(1).

[29] Yudha, S. K. (2020). BPS: 42 Persen Pebisnis Terancam Gulung Tikar. Republika. https://www.republika.id/posts/10231/bps-42-persen-pebisnis-terancam-gulungtikar
Lifestyle, Service Quality,

Promotion,

Purchasing Decision 